\title{
Interaction of 1-Methylcyclopropene and Thidiazuron on Cut Stock Flowers Vase Life
}

\author{
Antonio Ferrante ${ }^{*}, 1$, Alice Trivellini ${ }^{1}$ and Anna Mensuali-Sodi ${ }^{2}$ \\ ${ }^{1}$ Department of Agricultural and Environmental Sciences, Università degli Studi di Milano, Italy \\ ${ }^{2}$ Scuola Superiore Sant'Anna, Pisa, Italy
}

\begin{abstract}
Leaf yellowing or petal senescence is the main postharvest disorder for many cut flowers. Plant hormones such as cytokinins are able to inhibit leaf yellowing in some cut flowers and potted plants. In our experiments, we applied thidiazuron aiming to delay leaf yellowing and 1-methylciclopropene (1-MCP) for inhibiting flower senescence of cut stock flowers during vase life. Cut flowers were pulse treated with water (control), $5 \mu \mathrm{M}$ TDZ, $500 \mathrm{~nL} \mathrm{~L}^{-1} 1$-MCP or combinations $5 \mu \mathrm{M}$ TDZ+500 nL L ${ }^{-1}$ 1-MCP, $5 \mu \mathrm{M}$ TDZ $+500 \mathrm{~nL} \mathrm{~L}^{-1} 1-\mathrm{MCP}+10 \mu \mathrm{L} \mathrm{L}^{-1}$ ethylene or $10 \mu \mathrm{L} \mathrm{L}^{-1}$ ethylene. All treatments were applied for $24 \mathrm{~h}$ (pulse), except for the 1-MCP that was applied for $6 \mathrm{~h}$. The effect of treatments was evaluated by chlorophyll determination, petal fall, leaf yellowing appearance, vase life and ethylene production.

Pulse treatment with TDZ was able to delay leaf yellowing in light during whole experimental period (30 days). During the first days after TDZ treatment, the chlorophyll $b$ biosynthesis was strongly induced, after 5 days were the initial values, 3-fold higher while the total chlorophyll did not change. The TDZ stimulated ethylene production such as 1-MCP as soon as after $24 \mathrm{~h}$. The ethylene production was found in cut flowers treated with ethylene, reaching $9 \mathrm{nl} \mathrm{g}^{-1} \mathrm{~h}^{-1}$ in leaves and $6.5 \mathrm{nl} \mathrm{g}^{-1} \mathrm{~h}^{-1}$ in detached flowers. The 1-MCP dramatically reduced the efficiency of TDZ even if the vase life of cut flowers was extended compared with controls.
\end{abstract}

Keywords: Chlorophyll, ethylene, 1-MCP, postharvest, senescence, TDZ.

\section{INTRODUCTION}

Quality losses of cut flowers during the postharvest stage can be due to petal wilting, abscission, colour changes, leaf yellowing or weight loss. Some cut flowers are sensitive to leaf yellowing which occurs before petal wilting and lose their commercial value. The physiological disorders responsible for chlorophyll loss are mainly driven by hormonal and environmental factors [1-3]. Ethylene and abscisic acid are triggers of flower senescence or leaf yellowing [4]. Several cut flowers show chlorophyll loss before petal wilting such as Alstroemeria spp., Lilium, Matthiola incana, Pelargonium, Euphorbia pulcherrima. One of the main factors involved in the induction of chlorophyll degradation is the lack of cytokinins. This plant hormone is preferentially biosynthesized in roots [5]. Therefore, after harvest cut flowers do not receive cytokinins and leaf yellowing takes place. The postharvest treatments with benzyladenine applied as spray or in vase water, usually prevent or reduce the leaf yellowing appearance. Among the environmental issues, dark greatly activates leaf yellowing process. Cut flowers may be more or less sensitive to leaf yellowing depending from the species and cultivars [6]. The presence of ethylene in the cold rooms or supermarket enhances the leaf yellowing, but also accelerates flower senescence [7]. However, commercial formulations are available for preventing leaf yellowing of cut

*Address correspondence to this author at the Department of Agricultural and Environmental Sciences, Università degli Studi di Milano, Italy; Tel: +39 0250316589; Fax: +39 02 50316575;

E-mail: antonio.ferrante@unimi.it flowers [8]. Usually, they contain cytokinins (6-benzyladenine) or gibberellic acids $\left(\mathrm{GA}_{3}, \mathrm{GA}_{4}\right.$ and $\left.\mathrm{GA}_{4+7}\right)$. Exogenous applications of cytokinins can greatly delay leaf discoloration [9]. Exogenous applications of $\mathrm{GA}_{3}$ with concentrations that ranged between $10^{-4}$ and $10^{-5} \mathrm{M}$ were able to prevent leaf yellowing of cut alstroemeria flowers [9, 10]. In this species it has been found that leaf yellowing can be greatly delayed either by a pulse treatment for $24 \mathrm{~h}$ with 5 $\mu \mathrm{M}$ thidiazuron (TDZ). The TDZ both inhibits chlorophyll degradation and stimulates new chlorophyll biosynthesis [11]. The aim of this work was to investigate the effect of TDZ in combination with 1-MCP, an efficient inhibitor of ethylene action, on leaf yellowing and flower senescence of cut stock flowers. The synergism between TDZ and other plant growth regulators may be useful for preventing leaf yellowing of cut flowers dark stored or transported for a short or long period of time.

\section{MATERIALS AND METHODOLOGY}

\section{Plant Material}

Cut stock (Matthiola incana L.) flowers were directly bought from a cooperative of flower growers (Florexport, Viareggio Italy). Cut flowers were selected to avoid malformations or damage related with harvesting and transport handling. Cut flowers were cut to $60 \mathrm{~cm}$ and the basal leaves were removed. Each stem had 10-15 leaves in total. The whole cut flowers, with leaves and inflorescences, were used in the experiments. The experiments were repeated three times using cut flowers grown from January to March. 


\section{Chemical Treatments}

Cut flowers were pulse treated for $24 \mathrm{~h}$ (expect 1-MCP) in postharvest laboratory under conditions described above. After the pulse treatment the vase solutions were replaced with distilled water. The 1-MCP treatment instead was applied only for $6 \mathrm{~h}$ in airtight container then was taken out and left with others pulse treatments.

Flower stems were cut to $60 \mathrm{~cm}$ and placed in distilled water (control) or vase solution containing $5 \mu \mathrm{M}$ thidiazuron (TDZ, Duchefa), $500 \mathrm{~nL} \mathrm{~L}^{-1}$ 1-methylciclopropene (1-MCP, AgroFresh) or combination of $500 \mathrm{ppb} 1$-MCP plus $5 \mu \mathrm{M}$ TDZ, 500 ppb 1-MCP plus ethylene, 500 ppb 1-MCP plus 5 $\mu \mathrm{M}$ TDZ plus $10 \mu \mathrm{L} \mathrm{L}^{-1}$ ethylene, finally $10 \mu \mathrm{L} \mathrm{L}^{-1}$ ethylene.

Cut flowers were placed in a postharvest room maintained at $20{ }^{\circ} \mathrm{C}, 60 \%$ relative humidity and $15 \mu \mathrm{mol} \mathrm{m} \mathrm{m}^{-2} \mathrm{~s}^{-1}$ light intensity for $12 \mathrm{~h} \mathrm{day}^{-1}$ by cool-white fluorescent lamps.

\section{Chlorophyll Determination}

Total chlorophyll was determined from $10 \mathrm{~mm}$ diameter discs (3 discs for each sample) sampled from middle leaves of the stem. Leaf pigments were extracted using 99\% methanol and samples were kept in darkness at $4{ }^{\circ} \mathrm{C}$ for $24 \mathrm{~h}$. The absorbance readings were taken at 665.2 and $652.4 \mathrm{~nm}$. Total chlorophyll content was calculated as described by Lichtenthaler [12].

\section{Ethylene Production}

Ethylene production was measured enclosing flowers detached from the spikes or leaf disks in airtight containers $(30 \mathrm{ml})$. Two $\mathrm{ml}$ gas samples were taken from the headspace of the containers with a hypodermic syringe after $1 \mathrm{~h}$ incubation at room temperature. The ethylene concentration in the sample was measured by gas chromatograph (HP5890, Hewlett-Packard, Menlo Park, CA) using a flame ionisation detector (FID), a stainless steel column ( 150 x 0,4 cm ø packed with Hysep T), column and detector temperatures of 70 and $350{ }^{\circ} \mathrm{C}$, respectively, and nitrogen carrier gas at a flow rate of $30 \mathrm{ml} \mathrm{min}^{-1}$. Quantification was performed against an ex- ternal standard and results were expressed on a fresh weight basis (pl h ${ }^{-1} \mathrm{~g}^{-1}$ F.W.).

\section{Leaf Yellowing, Flower Senescence and Vase Life}

The effect of chemical treatments was evaluated by daily monitoring leaf yellowing and petal abscission appearance. The useful vase life was considered as the minor value between the leaf yellowing and flower senescence.

\section{Statistical Analysis}

The data are reported in figures and table as means with standard errors. Each treatment was composed of six replicate stems. The data were subjected to one-way or two-ways analysis of variance and the differences among treatments were analysed by Bonferroni's multiple comparison test. Experiments were repeated at least three times.

\section{RESULTS}

\section{Leaf Yellowing, Flower Life and Vase Life}

The vase life of cut stock flowers was delayed by pulse treatments with $5 \mu \mathrm{M}$ TDZ up to 10 days. Leaf yellowing in $5 \mu \mathrm{M}$ TDZ treatment was inhibited during the whole experimental period (30 days). Flower senescence instead was also improved but was extended for only 3.8 days compared to controls (Table 1). In order to improve the overall vase life of cut stock flowers, the TDZ was also combined with 1MCP. This ethylene action inhibitor alone increased the vase life of cut stock flowers compared with the control but slightly improve the leaves quality (Table 1). The 1-MCP treatment combined with TDZ reduced the beneficial effect of TDZ on leaf yellowing, even if the treatment significantly delayed the leaf yellowing compared with control (Table 1).

Treatment with exogenous ethylene resulted in $100 \%$ flower abscission and leaf yellowing in few days However, 1-MCP or 1-MCP+TDZ treatments completely prevented the negative ethylene effect on cut flowers (Table 1).

Table 1. Leaf Yellowing, Flower Senescence (Days of Apparearence) and Vase Life (Minus Value between Leaf and Flower Senescence). Values are the Means with Standard Errors $(n=6)$.

\begin{tabular}{|c|c|c|c|}
\hline Treatments & Leaf yellowing & Flower senescence & Vase life \\
\hline $5 \mu \mathrm{M}$ TDZ & $30 \pm 0.00 \mathrm{a}$ & $10 \pm 0.84 \mathrm{a}$ & $10 \pm 0.84 a$ \\
\hline 500 ppb 1-MCP & $8.7 \pm 0.21 \mathrm{c}$ & $8.2 \pm 0.17 \mathrm{ab}$ & $8.2 \pm 0.17 \mathrm{ab}$ \\
\hline $500 \mathrm{ppb} 1-\mathrm{MCP}+10 \mu \mathrm{l} \mathrm{L}{ }^{-1}$ Ethylene & $7.5 \pm 0.22 \mathrm{~d}$ & $8.0 \pm 0.26 \mathrm{ab}$ & $7.5 \pm 0.22 \mathrm{ab}$ \\
\hline 500ppb 1-MCP+5 $\mu \mathrm{M}$ TDZ+10 $\mu \mathrm{L} \mathrm{L}-1$ Ethylene & $17.33 \pm 0.56 b$ & $9.5 \pm 0.72 a$ & $9.5 \pm 0.72 a$ \\
\hline $10 \mu \mathrm{l} \mathrm{L}{ }^{-1}$ Ethylene & $4.3 \pm 0.9 \mathrm{~d}$ & $3.4 \pm 0.6 \mathrm{c}$ & $3.4 \pm 0.6 \mathrm{c}$ \\
\hline
\end{tabular}

Data were subjected to one-way analysis of variance and differences among treatments were analysed by Bonferroni post-test. Different letters denote significant differences at $p<0.05$ for each column. 


\section{Chlorophyll Content}

Leaves of cut flowers pulse treated with TDZ did not show total chlorophyll reduction (Fig. 1C). Other chemical treatments showed lower total chlorophyll content.

The two chlorophyll pigments $a$ and $b$ had different behaviour in TDZ treated plants compared with other treatments. The chlorophyll a (Fig 1A) after 3 and 5 days slightly declined, and increased again after 10 days. Opposite trend was observed for chl $b$ (Fig. 1B) that sharply increased after 3 and 5 days and slightly declined after 10 days. The 1-MCP alone or in combination with ethylene delayed the chlorophyll reduction if compared with control. On the contrary after 10 days of vase life, if 1-MCP was used in combination with TDZ, both compounds lost the ability to prevent chlo-

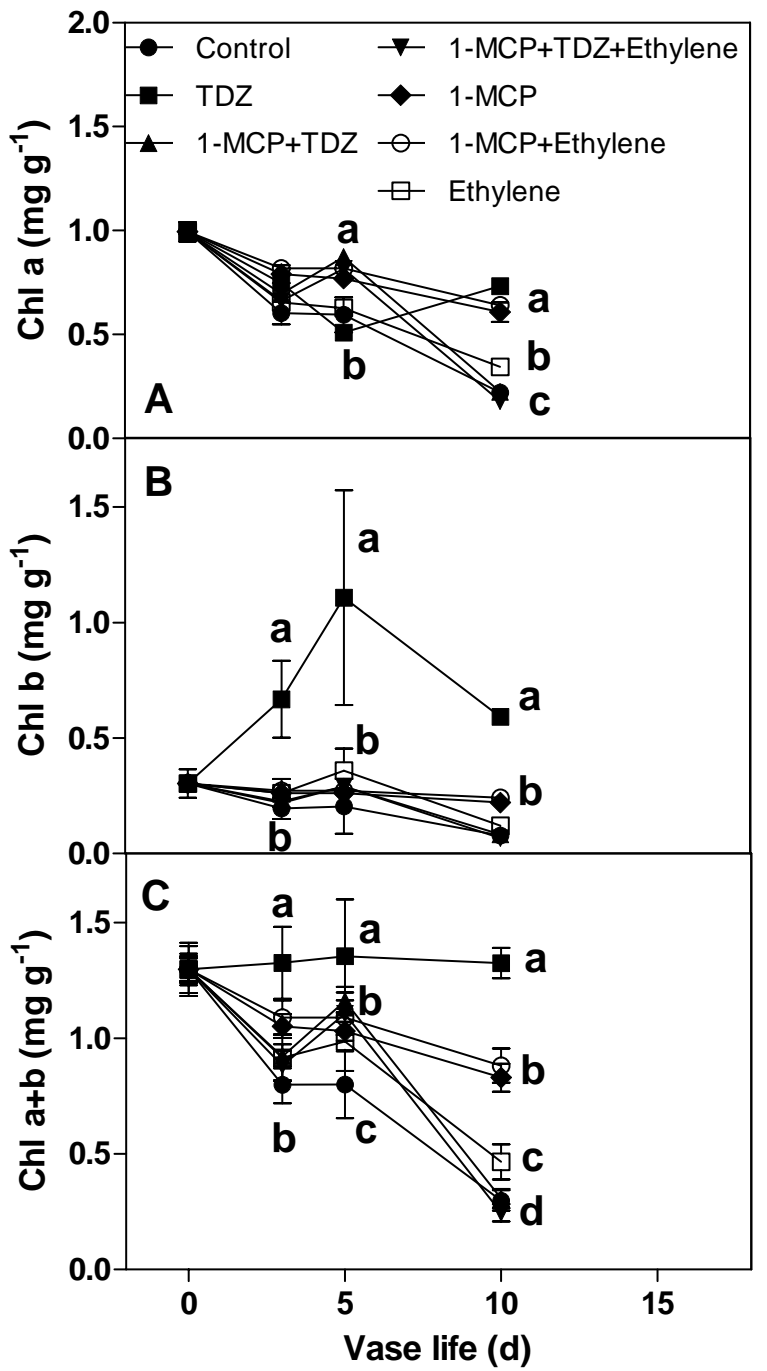

Fig. (1). Chlorophyll a (A), b (B)and a+b (C) concentration (mg g g $^{-1}$ F.W.) of cut stock leaves harvested from cut flowers pulse treated, distilled water (Control), $5 \mu \mathrm{M}$ TDZ , $500 \mathrm{ppb} 1-\mathrm{MCP}, 10 \mu \mathrm{L}^{-1}$ $\mathrm{C}_{2} \mathrm{H}_{4}, 500 \mathrm{ppb} 1-\mathrm{MCP}$ plus $10 \mu \mathrm{L} \mathrm{L}^{-1} \mathrm{C}_{2} \mathrm{H}_{4}$ or $5 \mu \mathrm{M}$ TDZ, $500 \mathrm{ppb}$ 1 -MCP plus $5 \mu \mathrm{M}$ TDZ plus $10 \mu \mathrm{L}^{-1} \mathrm{C}_{2} \mathrm{H}_{4}$. Values are the means with the relative standard errors of six leaves randomly harvested. Data were subjected to two-way analysis of variance and differences among treatments were analysed by Bonferroni post-test. Different letters denote significant differences at least $p<0.05$. rophyll losses and there were not significant differences compared with control (Fig. 1C).

\section{Ethylene Production}

Ethylene production was only measured in treatments that improved the vase life or in treatments that influenced the ethylene biosynthesis and action.

Ethylene biosynthesis was stimulated by all treatments and after $24 \mathrm{~h}$ the highest production was found in leaves treated with 1-MCP+TDZ+ethylene. After five days the ethylene production was not statistically different among treatments. After ten days the higher ethylene production was found from leaves of control and 1-MCP+TDZ+ethylene treated plants (Fig. 2A).

Ethylene production measured from open flowers detached from the inflorescence (Fig. 2B) was enhanced only after $24 \mathrm{~h}$ by $1-\mathrm{MCP}+\mathrm{TDZ}+$ ethylene treatment.

\section{DISCUSSION}

Stock flowers are very sensitive to leaf yellowing that usually occurs within 4-10 days after harvest [13]. Application of TDZ in vase water for $24 \mathrm{~h}$ completely inhibited chlorophyll loss as reported in previous works [14] of cut flowers or potted plants $[12,13,15,16]$. The treatment with TDZ prevented the chlorophyll degradation or even in-

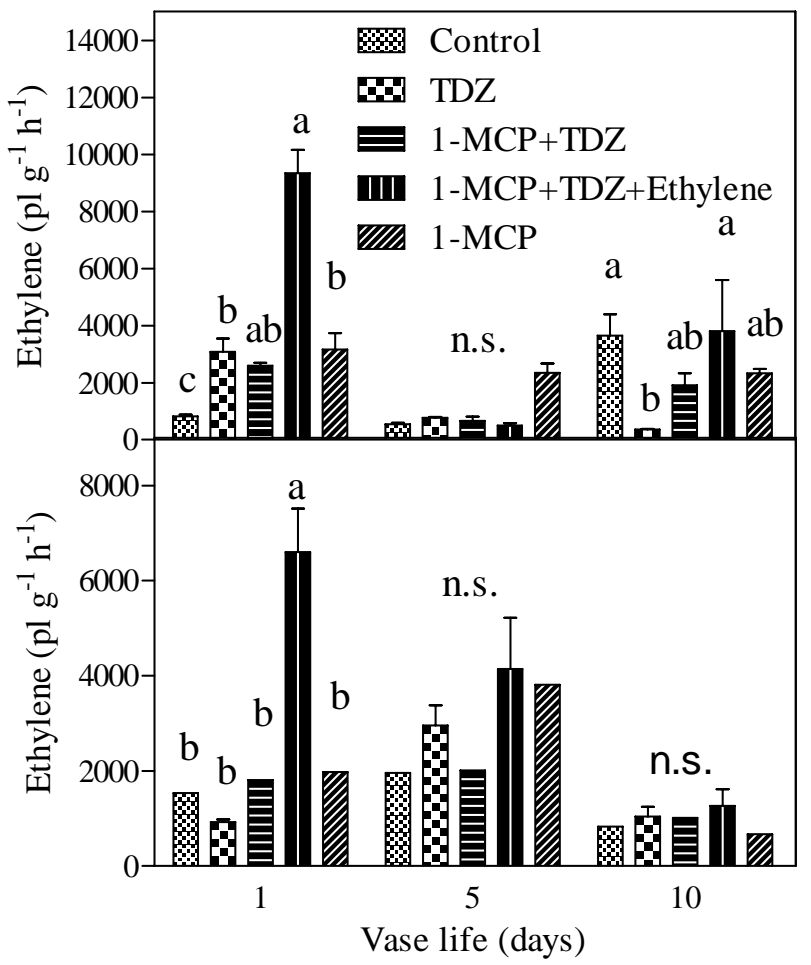

Fig. (2). Ethylene production from leaves of cut stock harvested from cut flowers pulse treated for $24 \mathrm{~h}$, distilled water (Control), 5 $\mu \mathrm{M}$ TDZ, $500 \mathrm{ppb} 1-\mathrm{MCP}, 500 \mathrm{ppb} 1$-MCP plus $5 \mu \mathrm{M}$ TDZ, 500 ppb 1-MCP plus $5 \mu \mathrm{M}$ TDZ plus $10 \mu \mathrm{L}^{-1} \mathrm{C}_{2} \mathrm{H}_{4}$. Values are the means with the relative standard errors of six leaves randomly harvested. Data were subjected to two-way analysis of variance and differences among treatments were analysed by Bonferroni posttest. Different letters denote significant differences at least $p<0.05$. 
creased the leaf total chlorophyll content as observed in treated cut tulips or cut chrysanthemum [11,3]. Our results confirm the ability of TDZ to stimulate new chlorophyll biosynthesis.

Moreover, TDZ increased the ethylene production in cut stock flowers and these findings were in according with previously observations [17]. The ethylene produced by TDZ has been used for promoting leaf abscission in cotton plants [18]. Experiments performed on cotton demonstrated that TDZ induced abscission of young and mature leaves. The role of TDZ-induced ethylene during leaf abscission was extensively characterized using ethylene inhibitors such as silver thiosulfate that completely inhibited leaf abscission in intact cotton leaves [19]. On the basis of these results the lack of negative effect of TDZ in cut stock should be explained considering the tissues sensitivity to ethylene. This hypothesis might be justified considering the behaviour of transgenic plants that overproduce cytokinins. Transgenic petunia containing the construct SAG12:IPT that overexpressed cytokinins showed that the higher level of cytokinins reduced the sensitivity of flowers to exogenous ethylene [20].

The ethylene action inhibitors, instead, such as silver thiosulfate or 1-MCP were able to prevent flower senescence if flowers were exposed to $1 \mu \mathrm{L} \mathrm{L}^{-1}$ of ethylene [21].

In our experiments, 1-MCP+TDZ + ethylene dramatically stimulated ethylene production, but did not accelerate the senescence. Ethylene induced autocatalytic ethylene, but the leaves and flowers were protected by 1-MCP. The amount of ethylene produced was organ dependent, in fact the leaf response was much higher, 10 fold compared with control flowers, while flower response was just doubled in treated cut flowers compared with controls. The absence of ethylene deleterious effect may be again explained considering the low ethylene sensitivity of leaves and flowers. Moreover, the climacteric ethylene peak in these plants was delayed and flowers had longer life. However, further investigations should be carried out at molecular level by the isolation of genes encoding for ethylene receptors and studying if the TDZ affect the organ sensitivity.

The organ differential response was also observed in cut flowers treated with 1-MCP alone or in combination with TDZ. The increase of ethylene production was also observed in 1-MCP treated flowers. These findings were in according with previous observations in citrus, where the ethylene evolution was directly correlated with the concentration of 1MCP used [22]. In this case the lack of ethylene effect may be attributed to the 1-MCP treatment that blocked the ethylene receptors. The leaf yellowing was delayed 2.5 days compared with control by 1-MCP treatment. This effect on chlorophyll retain was already found in leafy veegtables. In fact, 1-MCP treatments avoided chlorophyll loss in rocket [23] and spinach leaves during storage [24]. The 1-MCP and TDZ used together lose their ability to counteract the chlorophyll degradation. No literature information are available to explain this result. Therefore, further experiments should be performed for understand this interaction. Moreover, 1-MCP did not efficiently prevent the flower senescence of cut stock flowers, suggesting that this ethylene inhibitor is not very effective on this species. Analogous results were already shown by comparative treatments between 1-MCP and STS in cut stock flowers $[8,13]$.

\section{CONCLUSION}

Results demonstrated that in light conditions the leaf yellowing can be avoided using pulse treatments with TDZ and the efficacy of the treatments can be seen at $5 \mu \mathrm{M}$. Combination of TDZ with 1-MCP is not advisable because does not give any beneficial effect or reduces the TDZ efficiency.

\section{ACKNOWLEDGEMENT}

This study was supported by the Tuscany Region with grant named: "Innovazione e qualificazione dei prodotti per la valorizzazione della Floricoltura Toscana e la rinaturalizzazione di aree antropizzati (VALFLORIA2)”.

\section{CONFLICT OF INTEREST}

The author(s) confirm that this article content has no conflicts of interest.

\section{REFERENCES}

[1] Reid MS, Kofranek AM. Postharvest physiology of cut flowers. Chroni Horticult 1980; 20(2): 25-7.

[2] Teixeira da Silva JA. The cut flower: postharvest considerations. J Biol Sci 2003; 3(4): 406-42.

[3] Ferrante A, Mensuali-Sodi A, Tognoni F, Serra G. Postharvest studies on leaf yellowing of chrysanthemum cut flowers. Adv Hortic Sci 2005; 19: 81-5.

[4] Reid MS. Ethylene and abscission. HortScience 1985; 20: 45-9.

[5] Sakakibara H. Cytokinins: activity, biosynthesis, and translocation. Annu Rev Plant Biol 2006; 57: 431-49.

[6] Ferrante A, Hunter DA, Wesley PH, Reid MS. Thidiazuron: a potent inhibitor of leaf senescence in Alstroemeria. Postharvest Biol Technol 2002; 25 (3): 333-8.

[7] Reid MS. Effects of low temperatures on ornamental flowers. Acta Hortic 1991; 298: 215-23.

[8] Celikel FG, Dodge LL, Reid MS. Efficacy of 1-MCP (1methylciclopropene) and promalin for extending the post-harvest life of oriental lilies (Lilium x "Mona Lisa" and "Stargazer"). Sci Hortic 2002; 93: 149-55.

[9] Jordi W, Stoopen GM, Kelepouris K, Van Der Krieken WM. Gibberellin-induced delay of leaf senescence of Alstroemeria cut flowering stems is not caused by an increase in the endogenous cytokinin content. J Plant Growth Regul 1995; 14(3): 121-7.

[10] van Doorn WG, Hibma J, de-Wit J. Effect of exogenous hormones on leaf yellowing in cut flowering branches of Alstroemeria pelegrina L. J Plant Growth Regul 1992; 11: 445-8.

[11] Ferrante A, Mensuali-Sodi A, Serra G, Tognoni F. Treatment with thidiazuron for preventing leaf yellowing in cut tulips, and chrysanthemum. Acta Hortic 2003; 624: 357-63.

[12] Lichtenthaler HK. Chlorophylls and carotenoids: pigments of photosynthetic membranes. Meth Enzymol 1987; 148: 350-82.

[13] Celikel FG, Reid MS. Postharvest handling of stock (Matthiola incana). HortScience 2002; 37(1): 144-7.

[14] Ferrante A, Mensuali-Sodi A, Serra G. Effect of thidiazuron and gibberellic acid on leaf yellowing of cut stock flowers. Cent Eur J Biol 2009; 4(4): 461-8.

[15] Sankhla N, Mackay WA, Davis TD. Reduction of flower abscission and leaf senescence in cut phlox inflorescences by thidiazuron. Acta Hortic 2003; 628: 837-41.

[16] Macnish AJ, Jiang CZ, Reid MS. Treatment with thidiazuron improves opening and vase life of iris flowers. Postharvest Biol Technol 2010; 56: 77-84

[17] Yip WK, Yang SF. Effect of thidiazuron: a cytokinin-active urea derivative in cytokinin-dependent ethylene production systems. Plant Physiol 1986; 80(2): 515-9. 
[18] Suttle JC. Disruption of the polar auxin transport system in cotton seedlings following treatment with the defoliant thidiazuron. Plant Physiol 1988; 86(1): 241-5.

[19] Suttle JC. Cytokinin-induced ethylene biosynthesis in nonsenescing cotton leaves. Plant Physiol 1986; 82(4): 930-5.

[20] Chang H, Jones ML, Banowetz GM, Clark DG. Overproduction of cytokinins in petunia flowers transformed with PSAG12-IPT delays corolla senescence and decreases sensitivity to ethylene. Plant Physiol 2003; 132(4): 2174-83.

[21] Serek M, Sisler EC, Reid MS. Effects of 1-MCP on the vase life and ethylene response of cut flowers. Plant Growth Regul 1995; 16: 93-7.
[22] Zhong GY, Huberman M, Feng XQ, Sisler EC, Holland D, Goren R. Effect of 1-methyleyclopropene on ethylene-induced abscission in citrus. Physiol Plant 2001; 113(1): 134-41.

[23] Koukounaras A, Siomos AS, Sfakiotakis E. 1-Methylcyclopropene prevents ethylene induced yellowing of rocket leaves. Postharvest Biol Technol 2006; 41: 109-11.

[24] Gerozeff GG, Micieli ME, Gomez F, et al. 1-Methyl cyclopropene extends postharvest life of spinach leaves. Postharvest Biol Technol 2010; 55: 182-5.

Received: April 20, 2012

Revised: June 04, 2012

Accepted: June 07, 2012

(c) Ferrante et al.; Licensee Bentham Open.

This is an open access article licensed under the terms of the Creative Commons Attribution Non-Commercial License (http://creativecommons.org/ licenses/by-nc/3.0/), which permits unrestricted, non-commercial use, distribution and reproduction in any medium, provided the work is properly cited. 